\begin{tabular}{|l|l|l|}
\hline \multicolumn{2}{|c|}{ PublisherInfo } \\
\hline \hline PublisherName & $:$ & BioMed Central \\
\hline \hline PublisherLocation & $:$ & London \\
\hline \hline PublisherImprintName & $:$ & BioMed Central \\
\hline \hline
\end{tabular}

\title{
Peptide-based vaccination against the HER-2/neu oncogenic
} protein

\begin{tabular}{|l|l|l||}
\hline \multicolumn{2}{|c||}{ ArticleInfo } \\
\hline \hline ArticleID & $:$ & 3653 \\
\hline \hline ArticleDOI & $:$ & $10.1186 /$ bcr-1999-66631 \\
\hline \hline ArticleCitationID & $:$ & 66631 \\
\hline \hline ArticleSequenceNumber & $:$ & 19 \\
\hline \hline ArticleCategory & $:$ & Paper Report \\
\hline ArticleFirstPage & $:$ & 1 \\
\hline \hline ArticleLastPage & $:$ & 4 \\
\hline \hline & & RegistrationDate : 1999-7-12 \\
\hline ArticleHistory & $:$ & OnlineDate \\
\hline \hline ArticleCopyright & $:$ & Current Science Ltd1999-7-12 \\
\hline \hline ArticleGrants & $:$ & \\
\hline \hline ArticleContext & $:$ & 1305822 \\
\hline \hline
\end{tabular}




\section{Keywords}

breast cancer, HER-2/neu, ovarian cancer, peptide, vaccine

\section{Introduction}

HER-2/neu is a 'self' tumor antigen overexpressed in approximately $25-40 \%$ of breast/ovarian cancers. Vaccine strategies are an attractive treatment option, although cancer vaccines targeting 'self' tumor antigens must overcome immunological tolerance if they are to be effective. One approach is the use of peptide-based vaccines, which could overcome tolerance to the whole protein by targeting the immune response towards non-immunodominant peptide portions of the antigen. This approach has been shown to be effective in rat models. Studies in rats have also shown that GM-CSF is a potent immune-adjuvant, presumably working via its action on dermal dendritic (antigen-presenting) cells.

\section{Aims}

The aim of this phase 1 study was to examine whether peptide vaccines with adjuvant GM-CSF are safe to administer and whether they are effective in inducing T-cell immunity to HER-2/neu protein in humans with overexpressing breast/ovarian cancer.

\section{Comments}

This very interesting study shows that the overexpression of HER-2/neu in breast/ovarian cancer has been shown to be of adverse prognostic significance, and there is a great deal of current research focussing on the treatment of such patients. Data have recently been presented on the effectiveness of HER-2/neu monoclonal antibodies (with and without chemotherapy) in the treatment of patients with overexpressing metastatic breast cancer.This study presents the alternative therapeutic approach of peptide vaccination, which is already being studied in melanoma, and appears promising. Peptide based vaccination may be particularly useful in patients with metastatic disease who have a very good/ complete response to initial cytotoxic treatment, or in overexpressing patients following adjuvant therapy. Obviously, a great deal more work is required, in particular to determine if the generation of specific T-cell responses actually leads to an antitumor effect. 


\section{Methods}

An initial eight patients were selected for study who all had tumors with HER-2/neu overexpression, no detectable (or minimal residual) disease at the time of study enrollment, and a competent immune system. The patients were randomised to receive a vaccine consisting of three peptides from the extracellular domain (ECD) or three peptides from the intracellular domain (ICD) of the HER-2/neu protein. The peptides were 15-18 amino acids long and had been highly selected, first by computer protein-sequence analysis, and then by their ability to elicit T-cell responses in vitro (results presented in earlier papers).Patients were immunised monthly for 6 months, each course consisting of two intradermal injections of three combined peptides and GM-CSF, always given in the same location. Tcell responses were evaluated prior to each vaccination by measurement of T-cell proliferation. Any delayed-type hypersensitivity (DTH) response was also recorded and measured. At the completion of the immunisation schedule, patients were skin tested by peptide injections at a distant site.

\section{Results}

ECD peptides: 4/4 patients developed peptide-specific T-cell responses; 3/4 developed HER-2/neu protein-specific responses.

ICD peptides: 4/4 patients developed peptide-specific T-cell responses; 3/4 developed HER-2/neu protein-specific responses.

Epitope spreading was observed in some patients, ie patients developed T-cell responses to parts of the HER-2/neu protein that were not a component of their peptide mix. DTH responses were observed in all but one patient. Two of the patients completed all six vaccinations and at final testing developed DTH responses at a site distant to the vaccination site. Biopsy of these sites showed marked lymphocytic infiltration, predominately CD3/CD4+.There was no significant toxicity, in particular, against other tissues that normally express HER-2/neu such as the lung, gut, and liver.

\section{Discussion}

Using peptide vaccines plus GM-CSF as an intradermal injection was an effective strategy in generating specific T-cell immunity. Theoretically, ICD peptides should be more immunogenic; however, immune responses were elicited by both the ICD and the ECD peptides and the responses appeared equivalent. Six of the eight patients developed HER-2/neu protein-specific T-cell responses. It would be expected that patients who fail to develop this response would be unlikely to experience an antitumor effect. Finally, the development of DTH responses at sites distant to the site of vaccination indicates that the T-cells generated have the ability to migrate and target the antigen. 


\section{References}

1. Disis ML, Grabstein KH, Sleath PR, Cheever MA: Generation of immunity to the HER-2/neu oncogenic protein in patients with breast and ovarian cancer using a peptide-based vaccine. Clin Cancer Res. 1999, 5: 1289-1297. 